\title{
An Analysis on Hemocytes Profile in Kijing Taiwan (Anodonta woodiana) and Water Quality in Freshwater Aquaculture Ponds
}

\author{
Dyah Ayu Wijayanti ${ }^{*}$, Asus Maizar Suryanto Hertika², Bagyo Yanuwiadi ${ }^{3}$ \\ ${ }^{1}$ Master Program of Environmental Resource Management and Development, Graduate School, University of Brawijaya, \\ Malang, Indonesia \\ ${ }^{2}$ Faculty of Fisheries and Marine Sciences, University of Brawijaya, Malang, Indonesia \\ ${ }^{3}$ Department of Biology, Faculty of Mathematics and Natural Sciences, University of Brawijaya, Malang, Indonesia
}

\begin{abstract}
Kijing Taiwan (Anodonta woodiana) is found in water with muddy substrate. Kijing Taiwan lives in bottom waters and is relatively settled. Kijing Taiwan is a filter feeder organism that can filter water and is able to survive in polluted environment, so it can be used as a bio-indicator of a water body. The study was conducted in the Public Hatchery Unit (UPR) Sumber Mina Lestari. Profile hemocytes in Taiwan Kijing influenced by environment pollution inducer among others. Hemocytes were observed consisting of Total Haemocyte Count (THC) and Differential Haemocyte Count (DHC). The results show that the profile of hemocytes (THC and DHC) of Kijing Taiwan is not polluted. Results from aquaculture pond water quality measurements indicate that the indicators of the water quality i.e. temperature, $\mathrm{pH}$, dissolved oxygen, and ammonia are still in normal limits. However, in TOM test, BOD and soil organic matter has exceeded the normal limits. The existence of organic matter became the medium of life for Kijing Taiwan, due to its role as a biofilter among other organic materials.
\end{abstract}

Keywords: Hemocytes Profile, Kijing Taiwan, Water Quality.

\section{INTRODUCTION}

Public Hatchery Unit (UPR) Sumber Mina Lestari is a regional center for the cultivation of freshwater fish. It is located in Banjartengah, Sumbersekar Village, District Dau, Malang Regency. There are mollusks that live inside Kijing Taiwan. To improve agricultural productivity, farmers are still dependent on the use of various chemicals such as inorganic fertilizers and pesticides [1]. The use of inappropriate dose of chemicals often leaves residues in the environment. Living organisms used as bio motor have the following criteria: are widely spread geographically, have ecological tolerance, are polynomials, have stable population, become indicators of ecosystem, have high pollution tolerance, and are easy to recognize. One living organism that meets the requirements as bio motor in aquaculture ponds of UPR Sumber Mina Lestari is the freshwater mussel or referred to as Kijing Taiwan (Anodonta woodiana).

Kijing Taiwan (A. woodiana) is a freshwater mussel found in waters with muddy substrate. Kijing Taiwan lives in bottom waters and is relatively settled. Kijing Taiwan is a filter feeder organism that can filter water and is able to survive in polluted environment, so it can be used as

\footnotetext{
${ }^{*}$ Correspondence author:

Dyah Ayu Wijayanti

Email : dyah.puny@gmail.com

Address : Graduate School, University of Brawijaya, Jl. Mayjen Haryono No. 169 Malang, 65145
}

a bio-indicator of a body of water. Pollutants that enter the body Kijing Taiwan can affect the haemocyte profile, and thus by analyzing Total Haemocyte Count (THC) and Differential Haemocyte Count (DHC) of Kijing Taiwan in aquaculture ponds of UPR Sumber Mina Lestari, we can examine and analyze the water quality that support the life of Kijing Taiwan. The results show that the profile of haemocyte (THC and DHC) of Kijing Taiwan is not polluted but there has been found hyaline cells in the stage of introduction of foreign objects; thus, it is clear that Kijing Taiwan can be utilized as an early indicator of water pollution [2].

\section{MATERIALS AND METHODS}

\section{Study Area and Sampling}

The descriptive qualitative method is used in determining haemocyte profile and water quality in freshwater aquaculture ponds at the location of the research. Sampling was conducted at three stations can be seen in Figure 1. Total 30 Kijing Taiwan was taken randomly at each station with the same weight and length criteria.

The study was conducted in aquaculture ponds in UPR Sumber Mina Lestari situated in in Banjartengah, Sumbersekar Village, District Dau, Malang Regency, East Java Province. The area of UPR Sumber Mina Lestari is 1.7 ha. The geographical location of the village of Sumbersekar is 112017'10.90"- 112057'00" EL and 7044'55.11"$8026^{\prime} 35.45^{\prime \prime} \mathrm{SL}$ at $25-26^{\circ} \mathrm{C}$ and $630-670 \mathrm{~m}$ above 
sea level. Rainfall in UPR Sumber Mina Lestari is an average of 875-3000 $\mathrm{mm}$ per year.

\section{Data Collection and Analysis}

Observation is made actively on Total Haemocyte Count (THC) [3] and Differential Analysis Results for Haemocyte Count (DHC) of Kijing Taiwan [4]. Observation on Haemocyte Differential Count (DHC) of Kijing Taiwan was done in three types of haemocyte cells, i.e. granulocytes, semi granulocytes, and hyalinosit. Granulocyte cell consists of granules in the cytoplasm and capable of phagocytosis and move resembles an amoeba, whereas hyaline cells have only a few granules. Semi granule has a larger shape than hyaline, elongated oval-shaped with few number but spread out. To determine the relationship between the environment and the metabolic status of bivalves, haemocyte system, and the development of pollution, bivalve haemocyte can be used as an environmental biomarker [2].

\section{Water Quality}

In this study, measurements on water quality in aquaculture ponds were done, because the water quality could support microbial life in it, especially Kijing Taiwan. Water quality (Table 1) parameters including physical parameters (temperature) and chemical parameters $(\mathrm{pH}$, dissolved oxygen, total organic matter, soil organic matter and ammonia). Each parameter was measured thrice for each station.

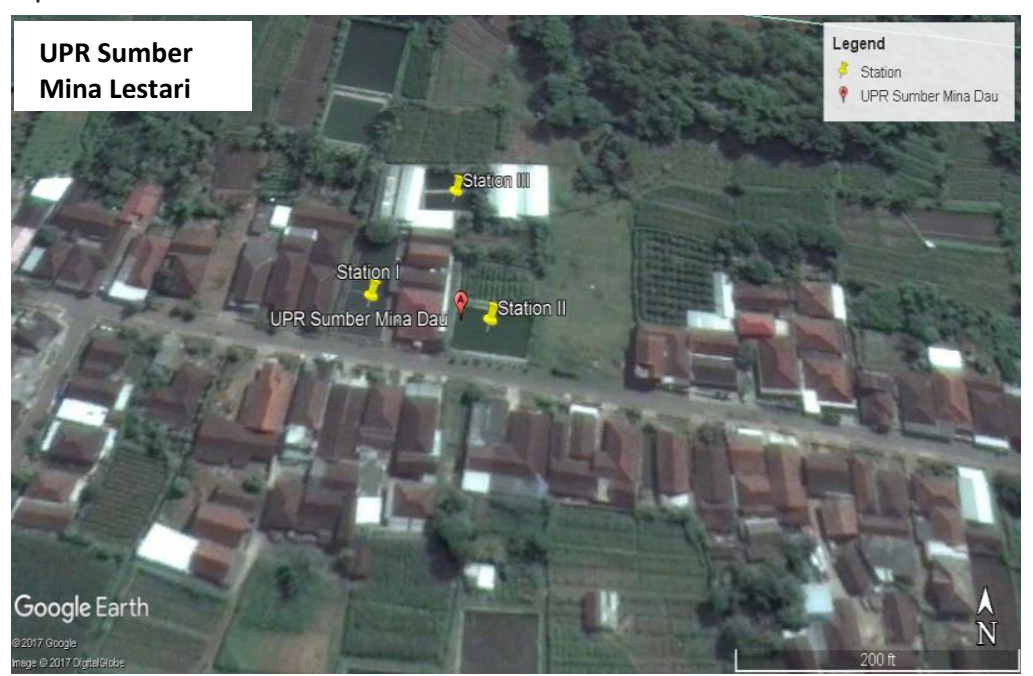

Figure 1. Location of the Research at Three Stations (Source: Google Earth, 2016)

Table 1. Haemocyte Count and Water Quality Measurement

\begin{tabular}{|c|c|c|c|c|c|}
\hline \multirow{2}{*}{$\frac{\text { No }}{1}$} & \multirow{2}{*}{$\begin{array}{l}\text { Method \& Measurement } \\
\text { Total Haemocyte Count } \\
\text { (THC) [3] }\end{array}$} & \multicolumn{2}{|l|}{ Tools } & \multicolumn{2}{|c|}{ Materials } \\
\hline & & $\begin{array}{l}\text { - } \text { Syringe } 1 \mathrm{~mL} \\
\text { - } \text { Cover glass } \\
\text { - } \text { Microscope }\end{array}$ & $\begin{array}{l}\text { oendorf } \\
\text { emocytometer } \\
\text { ashing bottle }\end{array}$ & $\begin{array}{ll}\text { - } & \text { Haemocyte of } \\
& \text { Kijing Taiwan } \\
\text { - } & \text { Na-citrate } 10 \%\end{array}$ & $\begin{array}{l}\text { - Trypanblue } 0.01 \% \\
\text { - Tissue } \\
\text { - Aquades }\end{array}$ \\
\hline 2 & $\begin{array}{l}\text { Differential Haemocyte Count } \\
(\mathrm{DHC})[4]\end{array}$ & $\begin{array}{l}\text { - Haemocyte } \\
\text { preparation }\end{array}$ & $\begin{array}{l}\text { croscope } \\
\text { ashing Bottle }\end{array}$ & $\begin{array}{l}\text { - Methyl alcohol } \\
\text { - Giemsa Solution }\end{array}$ & $\begin{array}{l}\text { - Tissue } \\
\text { - Aquades }\end{array}$ \\
\hline 3 & Temperature [5] & - Termometer $\mathrm{Hg}$ & - Stopwatch & - Ropes & - Tissue \\
\hline 4 & $\mathrm{pH}[6]$ & - Standard sheet of $\mathrm{pH}$ & - Stopwatch & - Ponds water & - pH paper \\
\hline 5 & Dissolved Oxygen (DO) [7] & $\begin{array}{l}\text { - } \text { DO bottle } \\
\text { - } \text { Drop pipet } \\
\text { - } \text { Burette } \\
\text { - } \text { Washing bottle }\end{array}$ & $\begin{array}{l}\text { - Funnels } \\
\text { - DO meter } \\
\text { - Statif }\end{array}$ & $\begin{array}{l}\text { - Ponds water } \\
\text { - } \mathrm{MnSO}_{4} \\
\text { - } \mathrm{NaOH}+\mathrm{KI} \\
\text { - } \mathrm{H}_{2} \mathrm{SO}_{4}\end{array}$ & $\begin{array}{l}\text { - Amylum } \\
\text { - } \mathrm{Na}_{2} \mathrm{~S}_{2} \mathrm{O}_{3} 0.025 \mathrm{~N} \\
\text { - Aquades } \\
\text { - Label paper }\end{array}$ \\
\hline 6 & $\begin{array}{l}\text { Total Organic Matter (TOM) } \\
\text { [8] }\end{array}$ & $\begin{array}{l}\text { - Erlenmeyer } \\
\text { - Burette }\end{array}$ & $\begin{array}{l}\text { - Statif } \\
\text { - Funnels }\end{array}$ & $\begin{array}{l}\text { - Ponds water } \\
\text { - } \mathrm{KMnO}_{4} \\
\text { - } \mathrm{H}_{2} \mathrm{SO}_{4}\end{array}$ & $\begin{array}{l}\text { - Aquades } \\
\text { - Label paper }\end{array}$ \\
\hline 7 & $\begin{array}{l}\text { Biological Oxygen Demand } \\
\text { (BOD) [9] }\end{array}$ & $\begin{array}{l}\text { - Erlenmeyer } \\
\text { - Statif } \\
\text { - Winkler bottle } \\
\text { - Washing Bottle }\end{array}$ & $\begin{array}{l}\text { - Burette } \\
\text { - Funnels } \\
\text { - DO bottle } \\
\text { - Drop pipet }\end{array}$ & $\begin{array}{l}\text { - Ponds water } \\
\text { - } \mathrm{NaOH}+\mathrm{KI} \\
\text { - Amylum } \\
\text { - Aquades } \\
\text { - Diluent solution }\end{array}$ & $\begin{array}{l}\text { - } \mathrm{MnSO}_{4} \\
\text { - } \mathrm{H}_{2} \mathrm{SO}_{4} \\
\text { - } \mathrm{Na}_{2} \mathrm{~S}_{2} \mathrm{O}_{3} 0.025 \mathrm{~N} \\
\text { - Label paper }\end{array}$ \\
\hline 8 & Soil Organic Matter [10] & $\begin{array}{l}\text { The organic carbon in } \\
\text { The chromium III forn } \\
\text { spectrometry. }\end{array}$ & $\begin{array}{l}\text { e sample is ox } \\
\mathrm{d} \text { is equivale }\end{array}$ & $\begin{array}{l}\text { with dichromate in } \\
\text { he oxidized C-orga }\end{array}$ & $\begin{array}{l}\text { an acidic atmosphere. } \\
\text { nic and measured by }\end{array}$ \\
\hline 9 & Ammonia [11] & Ammonia level was te & d with Spect & meter in Phenate $\mathrm{c}$ & ondition. \\
\hline
\end{tabular}




\section{RESULTS AND DICUSSION}

\section{Total Haemocyte Count (THC)}

Based on the research conducted, the granulocyte cells have a larger form and have granules in them. Otherwise, semi granulocyte cells are smaller than the granulocyte cells and larger than the hyaline cells. Hyaline cells have the smallest size and have no granule. The Total Haemocyte Count (THC) can be seen in Table 2.

\begin{tabular}{cc}
\multicolumn{2}{c}{ Table 2. Total Haemocyte Count for Kijing Taiwan } \\
\hline Station & Total Haemocyte Count (cell.ml ${ }^{-1}$ ) \\
\hline 1 & 76 \\
2 & 90.33 \\
3 & 40.33 \\
\hline
\end{tabular}

Based on the research results, Total Haemocyte Count (THC) for Kijing Taiwan taken in UPR Sumber Mina Lestari ranges from $40.33 \times 10^{4}$ to $90.33 \times 10^{4}$ cells. $\mathrm{mL}^{-1}$. The THC results indicate that the condition of Kijing Taiwan is unhealthy. It is in accordance with the previous study [12], the value of THC in bivalves must be between 6.4 $\pm 2.2 \times 10^{5}$ cells. $\mathrm{mL}^{-1}\left(64 \times 10^{4}\right.$ cells. $\left.\mathrm{mL}^{-1}\right)$. THC value above or below the normal range indicate bivalves reproduced in large quantities due to exposure of foreign material and pathogens.

\section{Differential Haemocyte Count (DHC)}

The first research result on Haemocyte Differential Count (DHC) is hyalinosit cells. The research results in UPR Sumber Mina Lestari show hyalinosit cells by $54 \%-57 \%$. Based on the research results obtained, it is known that Kijing Taiwan at the study site has not been polluted. This is in accordance with the previous study [2] that mentioned the uncontaminated hyalinosit on Crassotrea gigas range between $76.3-87.3 \%$. Hyalinosit value obtained in this study is more than $87.3 \%$, showing that granulocytes in Kijing Taiwan have been contaminated, as shown in Table 3.

Table 3. Differential Haemocyte Count for Kijing Taiwan

\begin{tabular}{cccc}
\hline \multirow{2}{*}{ Haemocyte Cells } & \multicolumn{3}{c}{ Differential Haemocyte Count (\%) } \\
\cline { 2 - 4 } & Station 1 & Station 2 & Station 3 \\
\hline Hyalinosit & 55 & 57 & 54 \\
Semi-granulocytes & 27 & 29.67 & 26.67 \\
Granulocytes & 18 & 13.33 & 19.33 \\
\hline
\end{tabular}

There are hyaline cells at UPR Sumber Mina Lestari; this happens due to foreign objects or pollutants in UPR Sumber Mina Lestari still in the introduction stage. Hyalineosit is the result of cell growth after going through several stages of maturation into granulocytes [13]. If hyalineosit cells are found more than granulocytes cells, then it can be suspected that the hemocytes are being introduced to foreign substances such as heavy metals and to subsequent encapsulation.

The high percentage of granulocytes and low percentage of hyalineosit will enhance the immune ability that will contribute to reducing vulnerability to disease attacks. At the time of introduction of the hyalineosit cells to foreign materials, the nucleus will release an enzyme called lectins enzymes, i.e. an enzyme that which will react with the surface of cells and increase the PPA (Prophenoloxidase Activating Enzyme). PPA is envisaged as part of the immune system that may be responsible for the introduction of a foreign object in the organism's defense system such as bivalves [13].

One form of organism's defense response to the condition of the body that does not support the increase in phagocytic cells playing role in enhancing the immune response is by increasing the ability of hemocytes cells for phagocytosis [14]. The abundance of circulating hemocytes is influenced by several factors, among others are sex, size, and body weight, and by external factors such as temperature, salinity, and dissolved oxygen [15].

The second result of research on Haemocyte Differential Count (DHC) is semi granulocytes. Semi granulocyte cells are mature form of hyaline cells -in the time of pathogen attacks, hyaline cells play the first role [15]. Based on the research results on Haemocyte Differential Count (DHC), semi granulocyte cells in UPR Sumber Mina Lestari show a value ranges from $26.67 \%$ to $29.67 \%$. This happens because of semi granulocyte cells in UPR Sumber Mina Lestari are in the introduction stage to stressors.

Semi granulocyte cells play a major role in the process of encapsulation and a little in the process of phagocytosis [16]. Semi granular cells function more in producing prophenoloxidase, an enzyme that plays a role in non-specific defense system. Activities of prophenoloxidase (PROPO) will free an enzyme from granular cells.

There are mitochondria in haemocytes as an intracellular key to the contamination of foreign objects because they are permeable and highly sensitive. Mitochondria accumulating heavy metals lead to disruption of energy balance. Bivalves have non adaptive immune system and they are able to eliminate pathogens depending on the cooperation of cellular and humoral mechanisms. Hemocytes in shellfish play a role to phagocytosis, especially in the response of immune cells to fight pathogens that enter the body [16]. According to Alifuddin [17], a 
component of foreign objects can activate cellular defense responses such as phagocytosis and encap-sulation. Cell antibodies can enhance the ability of hemocytes cell phagocytosis. Hemocytes as the immune system fight foreign substances such as heavy metal i.e. $\mathrm{Pb}$, and $\mathrm{Cd}$ through humoral and cellular expressed as Haemocyte Differential Count. Cellular immune response in shellfish contaminated with heavy metals will show different results, and it is possible to result in not only a decrease in the number of haemocytes but also an increase in the number of haemocytes and change the composition of haemocytes.

Based on the research results on granule cells, the granulocyte cells obtained range between $13.33 \%$ to $19.33 \%$. Based on these results, granulocyte cells obtained from UPR Sumber Mina Lestari can be said to be free from pollution. This is in accordance with previous study by Soil Research Institute [18], that uncontaminated granulocyte in shellfish shall show a value range between $11.24 \%$ to $22.4 \%$. Granulocytes value obtained is more than $22.4 \%$ signifying that granulocyte cells in Kijing Taiwan have been contaminated.

The granulocyte cells contained several cell organelles such as lysosomes, where lysosomes serves to hold the metals accumulated. The lysosome is a channel for the metal deposit [19]. Inside lysosomes, there are hydrolytic enzymes that are associated with cytoplasmic granules found in some species of mollusks. There is a trace of metal accumulation in cytoplasmic granules and an increase in the number of granulocytes in shellfish taken from contaminated environments. Granulocyte cells active in phagocytosis in oysters are a sign that there has been a response and internal resistance in the body of the oyster to the environment polluted by heavy metals such as $\mathrm{Pb}, \mathrm{Cd}$, and $\mathrm{Hg}$. Several enzymes are found in granulocytes i.e. amylase, glikogenase, lipase, protease, and the complex oxidation systems. Previous study showed that bivalves recast pollutants caused by the increase in the value of circulating hemocytes [20].

This happens because in UPR Sumber Mina Lestari, an introduction of contaminants occurs in hyaline cells. According to previous study [21], encapsulation is a reaction of immune defense against foreign substances and environmental influences. Granulocyte cells contain hydrolytic enzymes that play a role in phagocytosis against microbes that contribute to intracellular death.

\section{Water Quality of the Ponds}

In this study, measurements on water quality in aquaculture ponds were done, because the water quality could support microbial life in it, especially Kijing Taiwan. Water quality parameters measured in this study included temperature, $\mathrm{pH}$, dissolved oxygen, TOM, soil OM, and ammonia. The results of water quality measurements carried out in UPR Mina Lestari can be seen in Table 4.

Table 4. Value Range on Water Quality

\begin{tabular}{lcc}
\hline \multicolumn{1}{c}{ Parameter } & $\begin{array}{c}\text { Water } \\
\text { Quality }\end{array}$ & $\begin{array}{c}\text { Standards } \\
\text { Measurement } \\
\text { Result }\end{array}$ \\
\hline Temperature $\left({ }^{\circ} \mathrm{C}\right)$ & $25-26$ & $28-32[17]$ \\
Ph & 8 & $7-8.5[14]$ \\
DO (mg. $\left.\mathrm{L}^{-1}\right)$ & $7-8$ & $\geq 5[17]$ \\
TOM $\left(\mathrm{mg}^{-1} \mathrm{~L}^{-1}\right)$ & $28.89-36.67$ & $\geq 20[14]$ \\
BOD (mg. $\left.\mathrm{L}^{-1}\right)$ & $2.23-397$ & $3[20]$ \\
Soil Organic Matters (\%) & & $2-3[12]$ \\
Amonia (mg. $\left.\mathrm{L}^{-1}\right)$ & $0.44-1.16$ & $<0.02[20]$ \\
\hline
\end{tabular}

Results from water quality measurements indicate that the value of the indicators of the quality of the water, i.e. temperature, $\mathrm{pH}$ and dissolved oxygen are still in normal limits. However, TOM, BOD, soil organic matter and ammonia have all exceeded the normal limits. This leads to increased fertility of water due to high organic matter in the aquaculture ponds, so it is natural if the development of Kijing Taiwan happens rapidly because there are many natural food sources for Kijing Taiwan. The description of each indicator of water quality will be explained below.

\section{Temperature}

Temperature measurement was done in UPR Sumber Mina Lestari at $08.00 \mathrm{pm}$. Based on the research results, obtained temperature ranged between 25 to $26^{\circ} \mathrm{C}$ (Fig. 2). This showed that the temperature was good for the life of aquatic biota. Taiwan Kijing likes environment with a temperature of 24 to $29^{\circ} \mathrm{C}$. Kijing Taiwan can live in waters with temperatures between 11 to $29^{\circ} \mathrm{C}$.

Temperature is a very important factor in regulating the process of life and spread of the organism. The temperature of water is affected by atmospheric conditions, and the intensity of solar radiation entering the waters mainly in the surface layer. Temperature is influenced by seasons, the intensity of sunlight, air circulation, depth, and topography [22]. The life of bivalves is strongly influenced by temperature, which will affect the metabolism of bivalves, and the in- 
crease in temperature will increase the rate of metabolism.

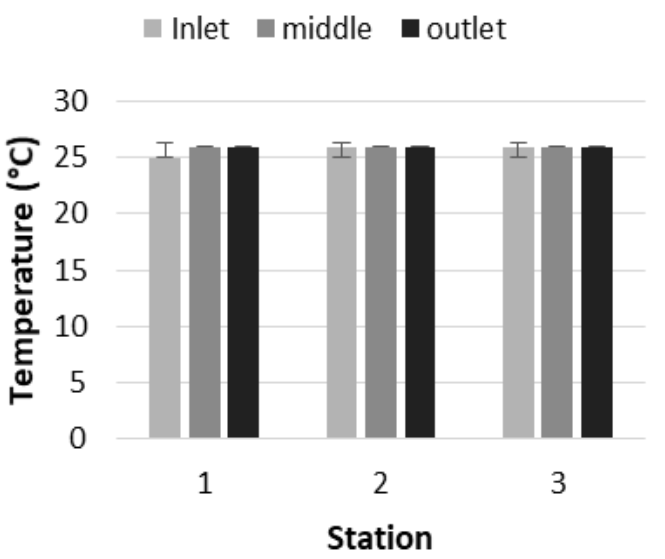

Figure 2. Temperature of Water in Ponds

Changes in temperature can affect the lives of aquatic organisms either directly or indirectly, but the change in the temperature can still be resolved by aquatic biota, where the temperature will affect the rate of metabolism, and the increase in temperature will increase the rate of metabolism [22].

pH

$\mathrm{pH}$ measurement in UPR Sumber Mina Lestari was done at $08.00 \mathrm{pm}$. $\mathrm{pH}$ is one of the limiting factors for the life of aquatic biota, one of which is bivalves. Each kind of organism has a different tolerance depending on the saturation levels of dissolved oxygen, alkalinity concentrations, and the type and stage of organisms [23]. Based on the research results, the $\mathrm{pH}$ obtained was 8 (Fig. 3 ). This indicates the $\mathrm{pH}$ was good. $\mathrm{pH}$ range supporting the life of bivalves must be between 6 to 9 [24]. Therefore, Kijing Taiwan could live well in the study site.

$$
\text { Inlet } \square \text { middle } \quad \text { outlet }
$$

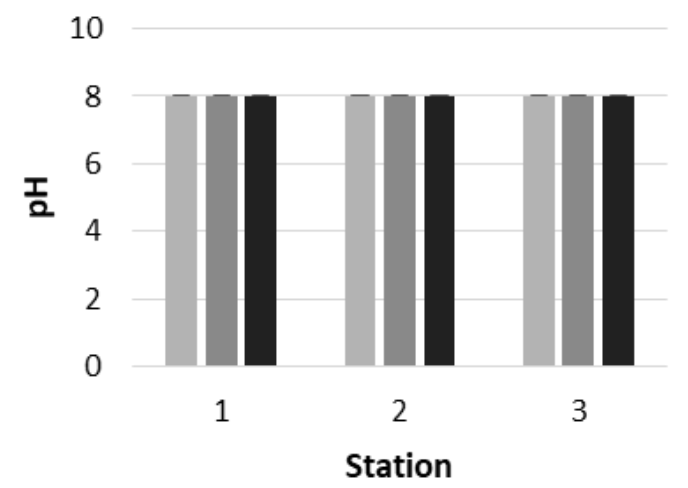

Figure 3. $\mathrm{pH}$ of Water in Ponds

The $\mathrm{pH}$ value can affect the properties of dissolved heavy metal. At high $\mathrm{pH}$, heavy metals will settle, while at low $\mathrm{pH}$ free ions are released into the water or the water column. In addition, $\mathrm{pH}$ affects toxicity of chemical compounds, and heavy metals will increase their toxicity at low $\mathrm{pH}$ [24].

\section{Dissolved Oxygen (DO)}

Measurement of dissolved oxygen carried out in UPR Sumber Mina Lestari at 08.00 pm. Based on the results, obtained dissolved oxygen was 7-8 mg. $\mathrm{L}^{-1}$ (Fig. 4). The results were considered good for biota as it was more than $5 \mathrm{mg} . \mathrm{L}^{-1}$. Thus, dissolved oxygen is essential for living organisms because it is used for the process of metabolism and respiration. The main source of oxygen in a body of water comes from a process of diffusion of free air and the results of photosynthetic organisms that live in the water.

$$
\square \text { Inlet } \square \text { middle } \square \text { outlet }
$$

$$
10
$$

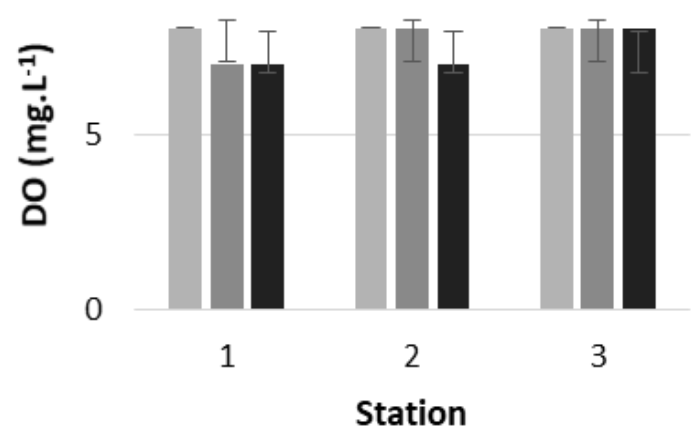

Figure 4. Dissolved Oxygen (DO) of Water in Ponds

The decomposition of organic and inorganic materials can reduce the oxidation of dissolved oxygen in the water until it reaches zero (anaerobic). Effect of dissolved oxygen to heavy metals is inversely proportional, in which the lower the dissolved oxygen, the higher the toxicity of heavy metals, and the vice versa [22].

\section{Total Organic Matter (TOM)}

Total Organic Matter (TOM) is the entire organic material that has not been or will undergo decomposition. The organic material is a food source for marine life. Based on the analysis of water quality, the value of total organic matter in Sumber Mina Lestari ranged from 28.89 to 36.67 mg. L $^{-1}$ (Fig. 5). 


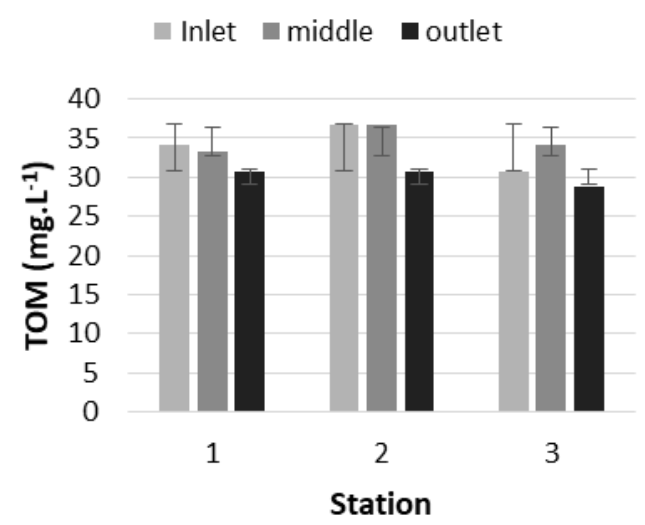

Figure 5. Total Organic Matter of Water in Ponds

Total Organic Matter (TOM) describes the total organic matter content in the water, consisting of dissolved organic matter, particulate, and colloids. The organic material can be used as a backup food for aquatic organisms, especially for organisms that live in bottom waters [25].

\section{Biological Oxygen Demand $\left(\mathrm{BOD}_{5}\right)$}

Biological Oxygen Demand $\left(\mathrm{BOD}_{5}\right)$ or biological oxygen requirement is the amount of oxygen needed by microorganisms in the water environment to break down organic waste material found in the water environment. Based on the analysis of water quality, the value of Biological Oxygen Demand (BOD 5 ) in Sumber Mina Lestari

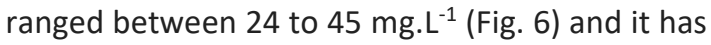
exceeded the normal threshold value at $3 \mathrm{mg} \cdot \mathrm{L}^{-1}$ [24].

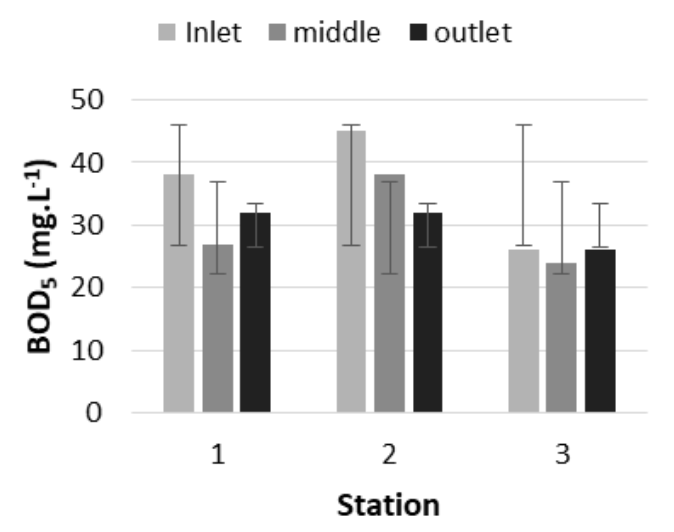

Figure 6. Biologycal Oxygen Demand of Water in Ponds

The high Biological Oxygen Demand $\left(\mathrm{BOD}_{5}\right)$ is influenced also by the high value of TOM, as high organic matter breakdown process is in line with the increased use of dissolved oxygen in the water. BOD is the amount of oxygen needed by microorganisms to solve organic materials in the water. BOD examination is required to determine the pollution load due to population or industrial waste water, and to design a water treatment system of polluted biolis. Breakdown of organic matter means that organic materials are used by organisms as food and energy obtained from the oxidation process [26].

\section{Soil Organic Matter}

The organic material in the soil of aquaculture ponds in UPR Sumber Mina Lestari was in the range of 2.23 to $3.97 \%$, which indicates that it has exceeded the normal limits set by the Soil Research Institute in 2005 at 3\%. See Figure 7.

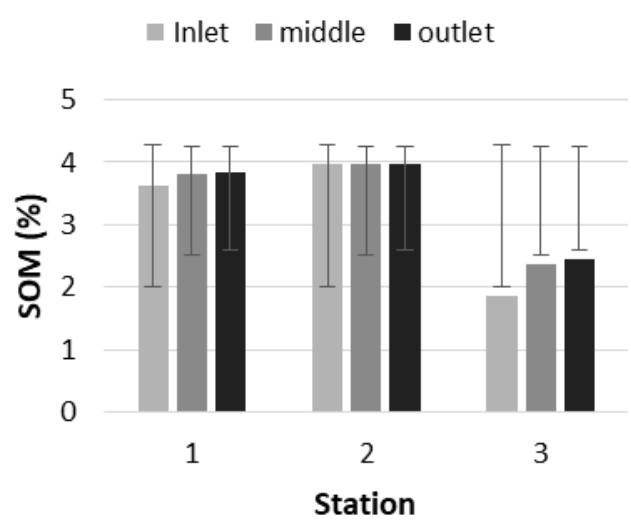

Figure 7. Soil Organic Matter of Water in Ponds

The highest value of soil organic matter was at station 2. This is because station 2 was the main pond used for collecting all the fish seed. Excessive accumulation of organic material in the bottom of the pond, the residual feed and fish feces, make soil organic matter content also increased. Increasing land organic matters will be followed by the high value of ammonia in the water [27].

\section{Ammonia}

Measurement of ammonia was also performed in UPR Sumber Mina Lestari. Based on the measurement of ammonia, the results obtained in the study ranging from 0.44 to 1.16 $\mathrm{mg} \cdot \mathrm{L}^{-1}$. Based on these results, the ammonia value exceeded the quality standard limits [28], which is $0.02 \mathrm{mg} \cdot \mathrm{L}^{-1}$. This is caused by the abundant residual fish feed in bottom waters. See Figure 8.

In natural waters, at normal temperature and pressure, ammonia is in the form of gas and will form equilibrium with ammonium ions [22]. In addition to gas, ammonia forms complexes with some metal ions. Ammonia measured in the water is the total ammonia $\left(\mathrm{NH}_{3}\right.$ and $\left.\mathrm{NH}_{4}^{+}\right)$. Free 
ammonia cannot be ionized (ammonia), while ammonium $\left(\mathrm{NH}^{+}\right)$can be ionized. The percentage of ammonia increases with increasing $\mathrm{pH}$ value and temperature of water. At $\mathrm{pH} 7$ or less, most of the ammonia will ionize [22].

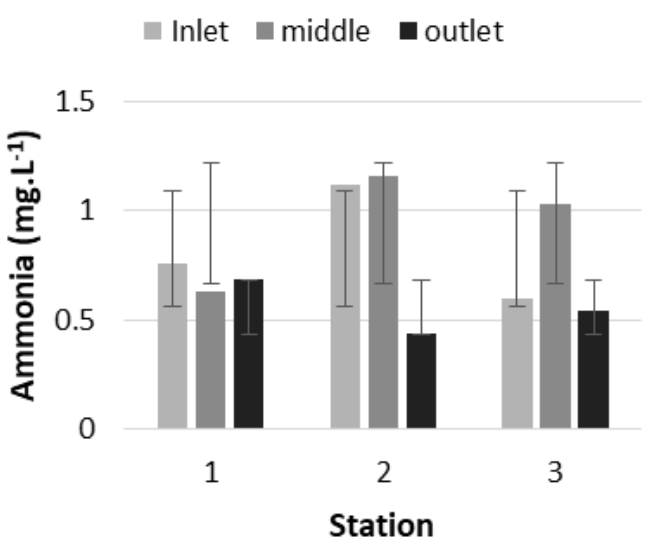

Figure 8. Ammonia of Water in Ponds

\section{CONCLUSION}

The results from to show that the profile of hemocytes: THC obtained indicate that the condition of Kijing Taiwan is unhealthy but the THC obtained is part of DHC. The DHC obtained from UPR Sumber Mina Lestari can be said to be free from pollution. Results from aquaculture pond water quality measurements indicate that the indicators of the water quality i.e. temperature, $\mathrm{pH}$ and dissolved oxygen are still in normal limits. However, in TOM test, BOD, soil organic matter and ammonia has exceeded the normal limits. The existence of organic matter became the medium of life for Kijing Taiwan, due to its role as a biofilter among other organic materials.

\section{REFERENCES}

[1] Personal Communication. 2016. Public Hatchery Unit (UPR) Sumber Mina Lestari. Malang Regency, Dau.

[2] Choi, H.J., J.Y. Hwang, D.L. Choi, M.D. Huh, Y.B. Hur, N.S. Lee, J.S. Seo, M.G. Kwon, H.S. Choi, M.A. Park. 2011. Non-specific defensive factors of the pacific oyster crassostrea gigas against infection with Marteilioides chuingmuensis: A Flowcytometric Study. Korean J. Parasitol. XLIX (3). 229-234.

[3] Ekawati, A.W., N. Happy, W. Edi, Marsoedi. 2012. Diatomae Chaetoceros ceratosporum dalam formula pakan meningkatkan respon imun seluler Udang Windu (Penaeus monodon Fab.). J. Exp. Life Sci. 2(1). 1-9.
[4] Tampangallo, B.R., S.P. Chalvyn, A. Rantetondok. 2012. Respon imun Udang Windu (Penaeus monodon) yang dipapar bakteri Vibrio harveyi. Proceeding of Seminar on National Fisheries. Fisheries Higher College. Jakarta.

[5] Bloom, J.H. 1998. Analisa mutu air secara kimiawi dan fisika: sebuah laporan tentang pelatihan dan praktek. NUFFIC UB. Faculty of Fisheries and Marine Sciences, University of Brawijaya. Malang.

[6] Subarijanti. 1990. Pemupukan dan kesuburan perairan. Faculty of Fisheries and Marine Sciences, University of Brawijaya. Malang.

[7] Suprapto. 2011. Metode Analisis Parameter Mutu Kualitas Air Untuk Budidaya Udang. Shrimp Club Indonesia. Pacitan.

[8] Indonesian National Standard. 1990. Metode pengukuran kualitas air. Public Work Service. Jakarta.

[9] Tebbutt, T.H.Y. 1992. Priciples of water quality control, $4^{\text {th }}$ Ed. Pergamon Press. Oxford.

[10] Darmono. 2001. Lingkungan hidup dan pencemaran: hubungannya dengan toksikologi senyawa logam. University of Indonesia Press. Jakarta.

[11] Indonesian National Standard. 2005. Cara uji kadar amonia dengan spektrofotometer secara fenat. Office of Indonesian National Standard.

[12] Delaporte, M., P. Soudant, J. Moal, C. Lambert, C. Quere, P. Miner. 2003. Effect of a mono-specific algal diets on immune function in two bivalve species Crassostrea gigas and Ruditapes philippinarum. J. Exp. Biol. 206 (Pt 17): 3053-64.

[13] Ottaviani, C., D. Shapiro, B.I. Goldstein, E.J. Jack, R. Weiss. 2006. Hemodynamic profile, compensation deficit, and ambulatory blood pressure. Psychophysiology. 43(1). 46 $-56$.

[14] Pipe, R.K., S.R. Farley, J.A. Coles. 1997. The separation and characterization of haemocytes from the mussel Mytilus edilus. Cell Tissue Resp. 289(1). 537-545.

[15] Sari, A.H.W., Y. Risjani, A.P.W. Mahendra. 2012. Efek Konsentrasi sublethal fenol terhadap Total Haemocyte Count (THC) dan histologi insang Kepiting Bakau (Scylla serata). J. Exp. Life Sci. 2(2). 82-88.

[16] Ekawati, A.W., H. Nursyam, E. Widjayanto, Marsoedi. 2012. Diatomae Chaetoceros ceratosporum dalam formula pakan 
mening-katkan respon imun seluler Udang Windu (Penaeus monodon Fab.). J. Exp. Life Sci. 2(1). 20-28.

[17] Alifuddin, M. 2002. Immune stimulation in aquatic animal. J. Aquaculture Indonesia. 1(2). 87-92.

[18] Soil Research Institute. 2005. Analysis of soil chemistry, plant, water and fertilizers. Agency for Agricultural Research and Development. Department of Agriculture. Bogor.

[19] Giamberini, L., M. Auffret, J.C. Pihan. 1996. Haemocytes the freshwater mussel, Dreissena polymorpha Pallas: cytology, cytochemistry and X-Ray microanalysis. J. Mollusca Stud. 62(1). 367-379.

[20] Mayrand, E., S.D. Jean, C.C. Simon. 2005. Haemocyte responses of blue mussels (Mytilus edulils L.) transferred from a contaminant et site to a reference site: the immune system can recuperate?. Aquac. Res. 36. 962-971.

[21] Triana, E., Y.N. Eko. 2006. Novik Test viability of Lactobacillus sp. Mar 8 encapsulated. Biodiversity. 7(2). 114-117.

[22] Effendi, H. 2003. Telaah Kualitas Air bagi Pengelolaan Sumberdaya dan Lingkungan Perairan. Yogyakarta: Kanisius.

[23] Ruswahyuni. 2010. Populasi dan Keanekaragaman Hayati Bentor Makro pada Perairan Tertutup dan Terbuka di Teluk Awur. Jepara. Sci. J. Fish. Mar. Resour. 2 (1). 1-10.

[24] Suwondo, E. F., S. Nurida. 2012. Kepadatan dan Distribusi Mangrove Bivalvia di Pantai Cermin. Sumatera Utara. J. Biogenesis. 9(1). 45-50.

[25] Hariyadi, S., Suryadiputra dan B. Widigdo. 1992. Limnologi Metode Kualitas Air. Fakultas Perikanan Institut Pertanian Bogor. Bogor.

[26] Wulandari, R. Y. S. 2011. Kajian Kadar Logam Berat Timbal $(\mathrm{Pb})$ pada Komunitas Periphyton di Enceng Gondok Sungai Lesti Desa Gampingan Kecamatan Pagak Kabupaten Malang. Fakultas Perikanan dan Ilmu Kelautan. Universitas Brawijaya Malang.

[27] Balai Penelitian Tanah. 2005. Analisis Kimia Tanah, Tanaman, Air dan Pupuk. Badan Penelitian dan Pengembangan Pertanian. Departemen Pertanian.

[28] Indonesian Government Regulation. 2001. No.82 about Management of water quality. Republic of Indonesia. 